\title{
Contribution of aloricate ciliates to the diet of Acartia clausi and Centropages hamatus in coastal waters
}

\author{
Peter Tiselius \\ Kristineberg Marine Biological Station, S-450 34 Fiskebäckskil, Sweden
}

\begin{abstract}
Clearance rates on natural assemblages of aloricate ciliates were determined for Acartia clausi and Centropages hamatus in coastal waters of the Kattegat, the Skagerrak and the Baltic. Ciliate concentrations ranged from 0.06 to $2.9 \mu \mathrm{gC}^{-1}$ equal to 0.4 to $2.9 \%$ of phytoplankton carbon. Clearance rates for $A$. clausi ranged from 7.9 to $15.0 \mathrm{ml} \mu \mathrm{gdw}^{-1} \mathrm{~d}^{-1}\left(27.7\right.$ to $52.5 \mathrm{ml}$ female $\left.{ }^{-1} \mathrm{~d}^{-1}\right)$ and for $C$. hamatus from 3.8 to $14.7 \mathrm{ml} \mu \mathrm{gdw}^{-1} \mathrm{~d}^{-1}\left(32.3\right.$ to $125.0 \mathrm{ml}$ female $\left.\mathrm{d}^{-1}\right)$. Clearance increased with ciliate size for both species, reaching a plateau for ciliates $>25 \mu \mathrm{m}$ ESD for $A$. clausi but not for C. hamatus. The size-dependent clearance rates were similar to previously reported rates on phytoplankton and no sign of size-independent preference for ciliates was observed. Copepod ingestion of ciliate carbon was always $<10 \%$ and generally $<1 \%$ of total carbon ingestion calculated from egg production measurements. The contribution of ciliates to the diet of $A$. clausi and $C$. hamatus was therefore negligible at the low (but typical) concentrations of aloricate ciliates in this study.
\end{abstract}

\section{INTRODUCTION}

It has lately been suggested that the microbial food web is the ultimate food resource for metazooplankton (Sherr \& Sherr 1988). The microbial loop is at times an important trophic pathway by which organic matter can be processed and made available to larger consumers (Sherr et al. 1986). For copepods, this is accomplished by ingestion of heterotrophic flagellates and ciliates.

The importance of ciliates as food for copepods has been stressed by e.g. Smetacek (1981), Frost (1987), Stoecker (1988) and has also been supported by experimental studies. Tintinnids, being the best known group of ciliates, have been used as prey in several copepod feeding studies and high clearance rates have been reported (Robertson 1983, Turner \& Anderson 1983, Stoecker \& Sanders 1985, Ayukai 1987, Stoecker \& Egloff 1987). The high experimental abundances of tintinnids used are occasionally attained in nearshore waters (P. Jonsson pers. comm.), commonly in tidal lagoons (Gifford 1986, Stoecker \& Egloff 1987, and others), but concentrations in coastal waters are usually lower.

Despite the fact that aloricate ciliates generally dominate the ciliate biomass (Sherr et al. 1986), they have rarely been used in experimental studies. Heinle et al. (1977) recorded high copepod egg production rates with a mixture of unidentified aloricate ciliates and Sheldon et al. (1986) found that the copepod Euterpina acutifrons preferred the aloricate ciliate Lohmaniella spiralis over diatoms, using high concentrations of ciliates $\left(103 \mu \mathrm{g} \mathrm{C}^{-1}\right)$.

The relative role of ciliates is thought to be quantitatively most important in waters where microbial circulation is pronounced, i.e. oceanic and stratified coastal waters. In the open, subarctic Pacific, ingestion of ciliates was reported necessary for the large Neocalanus plumchrus to fill its metabolic requirements (Gifford \& Dagg 1987). Kleppel et al. (1988) measured carotenoids associated with microzooplankton (including heterotrophic flagellates) in the guts of copepods off the Californian coast and between 23 and $97 \%$ of their diet appeared to consist of microzooplankton. In contrast, ciliate-dominated waters in the same area were associated with low copepod egg production (Kleppel 1987). For Acartia tonsa, microzooplankton represented 11 to $41 \%$ of total carbon ingestion when small flagellates $(<5 \mu \mathrm{m})$ dominated the phytoplankton, but only $3 \%$ when large diatoms $(>20 \mu \mathrm{m})$ were available (Gifford \& Dagg 1988).

In mixed coastal waters the phytoplankton biomass is 
usually dominated by larger algae and even though the production of organisms $<10 \mu \mathrm{m}$ can be appreciable (Sahlsten et al. 1988), the microbial loop is of less importance. When the seasonal thermocine has been formed, however, nutrient depletion favours small flagellates and the microbial loop becomes an important trophic pathway. Coastal copepods are therefore frequently faced with this food environment during the season of their highest abundance. Ciliates might be an important link between the copepods and the flagellates whose energy otherwise would be unavailable for the copepods, due to their small cell size (e.g. Berggreen et al. 1988, Sherr \& Sherr 1988).

Since the high concentrations of tintinnids used in most of the experiments are relatively seldom reached in nature, it is interesting to evaluate the role of the normally dominant aloricate ciliates at natural concentrations in the diet of coastal copepods. The question is: Do copepods display such a high feeding response to ciliates that, despite their low biomass, they become a significant source of nutrition?

Reported biomass of aloricate ciliates ranges from 0.3 to $36.8 \mu \mathrm{g} \mathrm{C}^{-1}$ for nearshore waters (Table 1 ). If the obligate autotroph Mesodinium rubrum is included, biomass can be considerably higher. In offshore waters, concentrations are usually lower, 0.04 to $7.3 \mu \mathrm{g} \mathrm{C} \mathrm{l}^{-1}$, and less variable. Thus the normal concentrations of ciliates a copepod would encounter are likely to be less than $40 \mu \mathrm{gC} 1^{-1}$ nearshore and less than $10 \mu \mathrm{g} \mathrm{C}^{-1}$ offshore. It is important to bear this in mind when judging the importance of ciliates in the copepod diet.

This paper reports feeding on ciliates and egg production of copepods from an $11 \mathrm{~d}$ time series conducted in the southern Kattegat between 31 May and 10 June 1988. Additional incubations from the Baltic and the Skagerrak were undertaken in August 1988. The water column in the Kattegat was stratified and algal concentration was low $\left(<0.5 \mu \mathrm{g} \mathrm{chl} a^{-1}\right)$ at the time of the study. Ciliates were therefore a potentially important alternative food source. Ciliate concentrations were representative for average, non-bloom periods in coastal waters. Egg production was used as an indirect measure of total carbon ingestion (Kiørboe et al. 1985) and by comparing total ingestion with ingestion of ciliates, the relative importance of aloricate ciliates in the diet of 2 small coastal copepods, Acartia clausi and Centropages hamatus, was evaluated.

\section{METHODS}

Time series in the Kattegat. Female Acartia clausi and Centropages hamatus were caught in the surface waters $(0$ to $10 \mathrm{~m})$ of the southern Kattegat $\left(58^{\circ} 11.6^{\prime} \mathrm{N}\right.$, $12^{\circ} 03.9^{\prime} \mathrm{E}$ ) between 31 May and 10 June 1988. Copepods were incubated in natural seawater with its natural concentration of ciliates. Water for incubations was collected from $3 \mathrm{~m}$ using a $30 \mathrm{I}$ Niskin bottle and

Table 1. Abundances and carbon concentrations of aloricate ciliates at different locations

\begin{tabular}{|c|c|c|c|}
\hline $\begin{array}{l}\text { Abundance } \\
\left(\text { No. } 1^{-1}\right)\end{array}$ & $\begin{array}{c}\text { Carbon } \\
\left(\mu \mathrm{gC} 1^{-1}\right)\end{array}$ & Habitat & Source \\
\hline $3800-50200$ & $0.8-10.0$ & Baltic coast & McKellar \& Hobro (1976) \\
\hline- & $0.5-34.0^{\mathrm{a}}$ & Baltic coast & Smetacek (1981) \\
\hline $4200-17500$ & $0.9-2.9$ & Baltic coast & This study \\
\hline $1400-162000^{d}$ & - & Shallow sound & Andersen \& Sórensen (1986) \\
\hline $1400-135200^{.5}$ & $0.4-30.0$ & Shallow sound & Andersen (1986) \\
\hline $5000-185000^{b}$ & $0.3-36.8$ & Tidal creek & Sherr et al. (1986) \\
\hline $0-87000^{\mathrm{b}}$ & $0-9.1$ & Open estuary & Sherr et al. (1986) \\
\hline $5-8800$ & - & Open estuary & Verity (1986) \\
\hline $3400-20400$ & $1.8-12.5$ & Embayment & Gifford \& Dagg (1988) \\
\hline 12000 & - & Coast & Burkill et al. (1987) \\
\hline $2900-13800$ & - & Coast & Gifford (1988) \\
\hline $350-6000$ & $0.04-3.6$ & Coast & Montagnes et al. (1988) \\
\hline $200-800$ & $0.06-0.4$ & Coast & This study \\
\hline $100-1370^{2}$ & - & Shelf & Paranjape et al. (1985) \\
\hline $0-17400^{b}$ & $0-2.1$ & Shelf & Sherr et al. (1986) \\
\hline $2500-4000$ & - & Shelf & Burkill et al. (1987) \\
\hline $570-13100^{\circ}$ & $0.7-7.3$ & Shelf & Stoecker et al. (1989) \\
\hline $1300-1340$ & $0.4-0.6$ & Shelf & This study \\
\hline \multicolumn{4}{|c|}{${ }^{a}$ Mesodinium sp. excluded } \\
\hline \multicolumn{4}{|c|}{${ }^{\circ}$ Ciliates $<20 \mu \mathrm{m}$ ESD only } \\
\hline \multicolumn{4}{|c|}{ "Chlorophyll a containing ciliates only } \\
\hline
\end{tabular}


screened through a $180 \mu \mathrm{m}$ net. Within $3 \mathrm{~h}$ of collection, 10 copepods of either species were added to $620 \mathrm{ml}$ screwcap bottles filled with the collected seawater. One start bottle was immediately preserved with acid Lugol's to a concentration of $1 \%$. Two controls (without animals) and 3 bottles each for each copepod species were incubated on a rotary wheel $(0.5 \mathrm{rpm})$ at $14^{\circ} \mathrm{C}$ under a 12:12 h light-dark cycle for $24 \mathrm{~h}$. At the end of the incubations, the entire contents of the bottles were preserved in acid Lugol's. Prior to analysis, the samples were concentrated on an $11 \mu \mathrm{m}$ mesh net, then rinsed into an Utermöhl chamber and counted after sedimenting overnight.

To investigate whether experimental procedures reduced the ciliate concentrations, natural seawater containing ciliates was sieved through a $180 \mu \mathrm{m}$ screen, preserved as above and compared to unfiltered, pre-

Table 2. Effects on ciliate abundance of filtering living ciliates through a $180 \mu \mathrm{m}$ mesh net and collecting ciliates preserved in Lugol's for $>24$ h on an $11 \mu \mathrm{m}$ mesh net

\begin{tabular}{|lcc|}
\hline Treatment & $\begin{array}{c}\text { Ciliate abundance } \\
\left.\text { (No. } \mathrm{ml}^{-1} \pm \mathrm{SD}\right)\end{array}$ & $\begin{array}{c}\text { No. } \\
\text { samples }\end{array}$ \\
\hline $\begin{array}{l}\text { Lugol's } \\
\text { Through } 180 \mu \mathrm{m} \\
+ \text { Lugol's }\end{array}$ & $7.59 \pm 0.48$ & 5 \\
$\begin{array}{l}\text { Through } 180 \mu \mathrm{m} \\
+ \text { Lugol's }+ \text { collecting on } 11 \mu \mathrm{m}\end{array}$ & $6.96 \pm 0.68$ & 5 \\
& & 5 \\
\hline
\end{tabular}

served samples (Table 2). Collection of ciliates (preserved $>24 \mathrm{~h}$ in Lugol's) on an $11 \mu \mathrm{m}$ mesh net was also compared to unfiltered samples (Table 2), but neither treatment caused any significant loss of ciliates or change in size distribution.

Growth of ciliates in the controls never exceeded $10 \%$ but mortality was occasionally severe. For the Kattegat incubations up to $40 \%$ mortality was observed, in the Skagerrak up to $80 \%$, whereas in the Baltic no mortality occurred. However, clearance rates did not vary in response to either mortality or growth of the ciliates.

For egg production measurements, 4 to 6 bottles with 3 adult female copepods each were incubated as above. At the end, the condition of the females was recorded and eggs counted. Only females living after the incubations were used in the calculations. Mortality was generally insignificant.

Skagerrak. Incubations using Acartia clausi females were carried out on board RV 'Dana' on 20 to 21 August 1988 at 2 stations, $58^{\circ} 12.7^{\prime} \mathrm{N}, 9^{\circ} 41.7^{\prime} \mathrm{E}$ and $58^{\circ} 01.4^{\prime} \mathrm{N}$, $10^{\circ} 01.0^{\prime} \mathrm{E}$. The same method was used, except that the bottles were incubated on deck in running seawater $\left(17^{\circ} \mathrm{C}\right)$.

Baltic Sea. Acartia bifilosa females and water were collected close to the Askö Laboratory $\left(58^{\circ} 49.0^{\prime} \mathrm{N}\right.$, $17^{\circ} 37.5^{\prime} \mathrm{E}$ ) on 6 and 10 August 1988 and treated as above. Incubation temperature was 13 to $15^{\circ} \mathrm{C}$.

All or the first 200 ciliates were measured (length or diameter) at $150 \times$ with an eyepiece micrometer. Cell volumes were calculated approximating the shape of the ciliate to a cone with length: diameter ratio of 1.25 for ciliates $<50 \mu \mathrm{m}$ and a ratio of 2 for ciliates 50 to $100 \mu \mathrm{m}$. The choice of shape strongly affects the calculated cell volume. For example, an ellipsoid shape with the same length: diameter ratio would yield twice the volume compared to a cone. Furthermore, ciliates tend to shrink because of fixation and this can cause underestimation of cell volumes.

To measure possible shrinkage due to fixation, cultured Strombidium reticulatum were analysed, both alive and preserved in Lugol's, with an Elzone $180 \mathrm{XY}$ particle counter. Mean cell volume of living ciliates was $24900 \mu^{3}$ ( $n=570$ ) and of preserved ciliates was $23600 \mu^{3}$ ( $n=353$ ) which corresponds to $5 \%$ shrinkage. This would not be observed if linear measurements under the microscope were used for volume calculations. I therefore conclude that the main source of error for determining ciliate cell volumes is the choice of geometrical shape and that the method chosen here gives a conservative estimate of cell volumes.

Particle concentrations in the seawater were measured with a particle counter: Coulter Multisizer 256 fitted with 140 and $560 \mu \mathrm{m}$ orifice tubes or Elzone $180 \mathrm{XY}$ with 95 and 300 um tubes.

Clearance and ingestion rates were calculated according to Frost (1972). The clearance rates vary with copepod size and are therefore expressed as $\mathrm{ml} \mu \mathrm{gdw}^{-1}$ $\mathrm{d}^{-1}$. Average cephalothorax lengths $( \pm \mathrm{SD}, \mathrm{n}=50)$ of female Acartia clausi were $0.705 \pm 0.03 \mathrm{~mm}$ (Kattegat), $0.887 \pm 0.03 \mathrm{~mm}$ (Skagerrak), $0.678 \pm 0.03 \mathrm{~mm}$ (A. bifilosa, Baltic) and for Centropages hamatus (Kattegat) $0.742 \pm 0.03 \mathrm{~mm}$

\section{RESULTS}

Ciliate concentrations during the time series study ranged from 0.2 to 0.8 ciliates $\mathrm{ml}^{-1}$ and estimated ciliate carbon from 0.057 to $0.407 \mu \mathrm{gC} \mathrm{l}^{-1}$ (Fig. 1). Strombidium spp. with size 15 to $50 \mu \mathrm{m}$ was always the numerically dominant ciliate. Laboea strobila was fairly common and various forms of the subclass Haptoria (Didinium sp. and others) increased after Day 7 to form a substantial part of the biomass by the end of the study period. In the central Skagerrak ciliate carbon was 0.37 to $0.62 \mu \mathrm{gC} \mathrm{I}^{-1}$ with the same species composition as in the Kattegat. In the Baltic concentrations were higher (0.95 to $\left.2.9 \mathrm{\mu g} \mathrm{C} \mathrm{I}^{-1}\right)$ with a dominance of small 


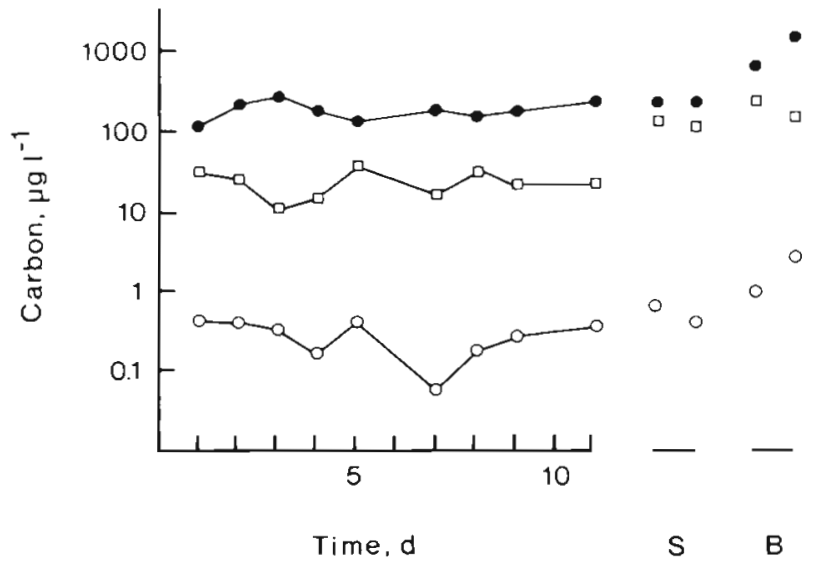

Fig. 1. Concentrations of total ( 3 to $200 \mu \mathrm{m}$ ) particulate carbon $(\bullet)$, phytoplankton carbon (ㅁ) and ciliate carbon (o) during the time series in the Kattegat (Days 1 to 11), in the Skagerrak (S) and the Baltic (B). Total carbon is calculated from particle volume using a carbon: volume ratio $=0.11 \mathrm{pg} \mathrm{C} \mu \mathrm{m}^{-3}$ (Strathmann 1967), phytoplankton carbon from chlorophyll a measurements using a $\mathrm{C}: \mathrm{chl}$ a ratio $=78$ (Eppley et al, 1977) and ciliate carbon from volumes using carbon:volume ratio = $0.071 \mathrm{pg} \mathrm{C} \mu \mathrm{m}^{-3}$ (Jonsson 1988)

$(<25 \mu \mathrm{m})$ Strombidium spp. and Mesodinium sp. Tintinnids were of insignificant quantitative importance on all occasions.

Particulate carbon in the 3 to $200 \mu \mathrm{m}$ size range, as estimated by electronic particle counts, varied between 120 and $280 \mu \mathrm{gC}^{-1}$ in the Kattegat with approximately similar values in the Skagerrak but much higher, 680 to $1500 \mu \mathrm{gC} \mathrm{l}^{-1}$, in the Baltic (Fig. 1). Phytoplankton carbon estimated from chlorophyll a was considerably lower ranging from 11 to $35 \mu \mathrm{gC} \mathrm{l}^{-1}$ in the Kattegat and 140 to $220 \mathrm{ug} \mathrm{Cl}^{-1}$ in the Baltic. The ciliate carbon constituted 0.15 to $0.5 \%$ of total 3 to $200 \mu \mathrm{m}$ particulate carbon or 0.4 to $2.9 \%$ of phytoplankton carbon.

Mean clearance by Acartia clausi was fairly constant for ciliates $>25 \mu \mathrm{m}$ ESD (Equivalent Spherical Diameter) ( 13.3 to $\left.15.0 \mathrm{ml} \mu \mathrm{gdw}^{-1} \mathrm{~d}^{-1}\right)$ but declined to $7.9 \mathrm{ml}$ $\mu \mathrm{gdw}^{-1} \mathrm{~d}^{-1}$ for the smallest (11.3 $\mu \mathrm{m}$ ESD) ciliate (Fig. 2). Centropages hamatus, in contrast, showed a steady increase from $3.8 \mathrm{ml} \mu \mathrm{gdw}^{-1} \mathrm{~d}^{-1}$ for the smallest cilite to $14.7 \mathrm{ml} \mathrm{\mu gdw}^{-1} \mathrm{~d}^{-1}$ for the 35 to $50 \mu \mathrm{m}$ ESD size fraction (Fig. 3).

The ingestion of ciliates by Acartia sp. was found to be proportional to ciliate concentration (Fig. 4), since the slope of the regression line is close to 1 . This also implies that the clearance rate was constant over the range of concentrations that Acartia sp. encountered and that the rather high reduction in ciliate numbers during the incubations (up to $40 \%$ of initial concentration) did not affect their clearance rate. Centropages hamatus had the same weight-specific ingestion rate

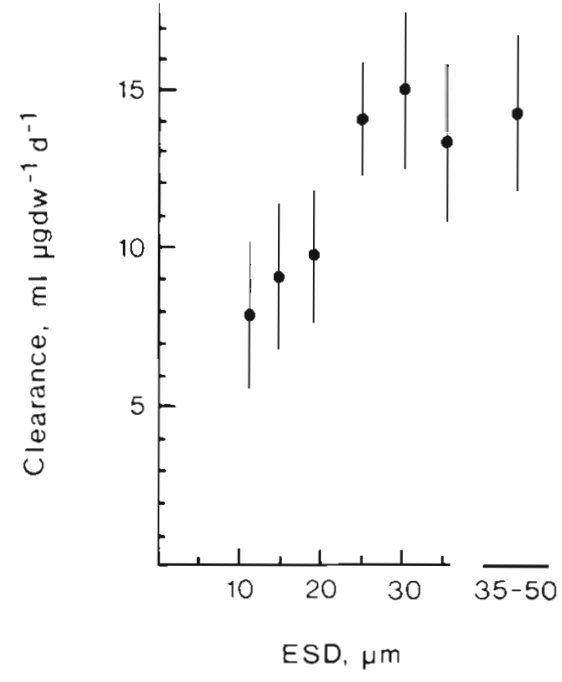

Fig. 2. Acartia clausi. Clearance rates on different sizes (ESD, Equivalent Spherical Diameter) of ciliates in natural plankton assemblages. All ciliates within a size range have been pooled and the clearance rates are averages over the entire time series. Dry weight of females was $3.5 \mu \mathrm{g}$ (from length-weight regressions in Durbin \& Durbin 1978). Error bars indicate $\pm \mathrm{SE}$

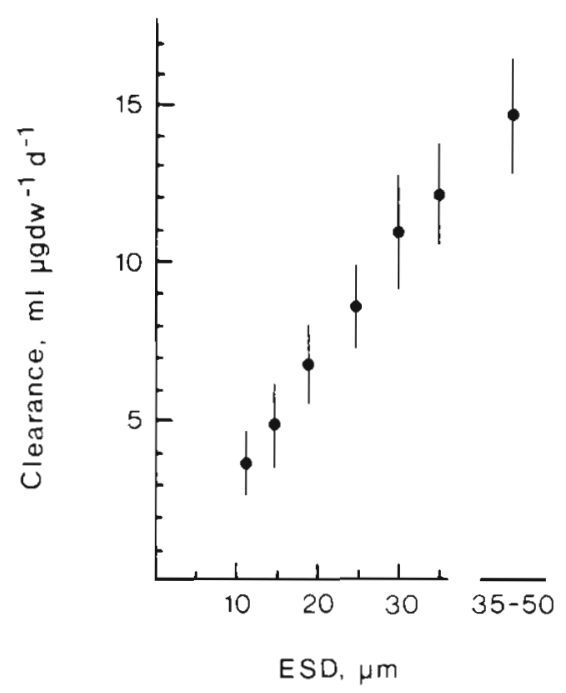

Fig. 3. Centropages hamatus. Clearance rates as in Fig. 2. Dry weight of females was $8.5 \mathrm{~kg}$ (from length-weight regressions in Klein Breteler et al. 1982)

but the data are inadequate for a linear regression analysis.

Egg production for Acartia clausi during the time series ranged from 9.7 to 17.5 eggs female ${ }^{-1} \mathrm{~d}^{-1}$, in the Skagerrak 4.8 to 5.6 eggs female ${ }^{-1} \mathrm{~d}^{-1}$ and in the Baltic 5.4 to 14.6 eggs female ${ }^{-1} \mathrm{~d}^{-1}$ (A. bifilosa). Egg production for Centropages hamatus was only determined during the time series and ranged from 7.2 to 19.9 eggs female ${ }^{-1} d^{-1}$. Egg production was converted to total 


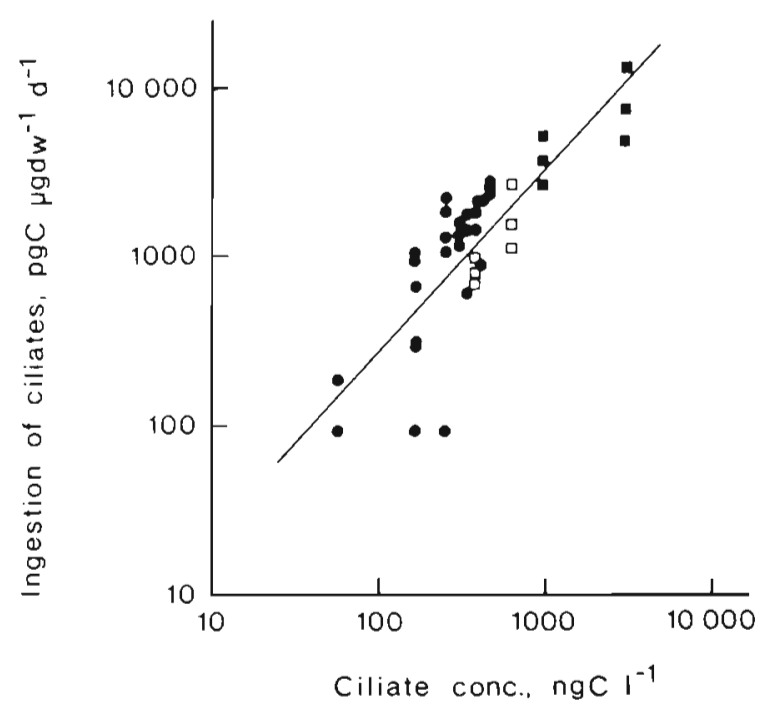

Fig. 4. Acartia sp. Ingestion of ciliates at various ciliate concentrations in natural seawater in the Kattegat $(\bullet)$, the Skagerrak () and the Baltic ( $\bullet$ ). Each dot represents one incubation with 10 females. The regression line is $\log y=1.05 \log x+$ $0.37, \mathrm{r}^{2}=0.65, \mathrm{n}=39$

carbon ingestion assuming a gross production efficiency of $33 \%$ (Kiørboe et al. 1985). There was no relationship between ingestion of ciliates and total ingestion (Fig. 5). During the entire time series

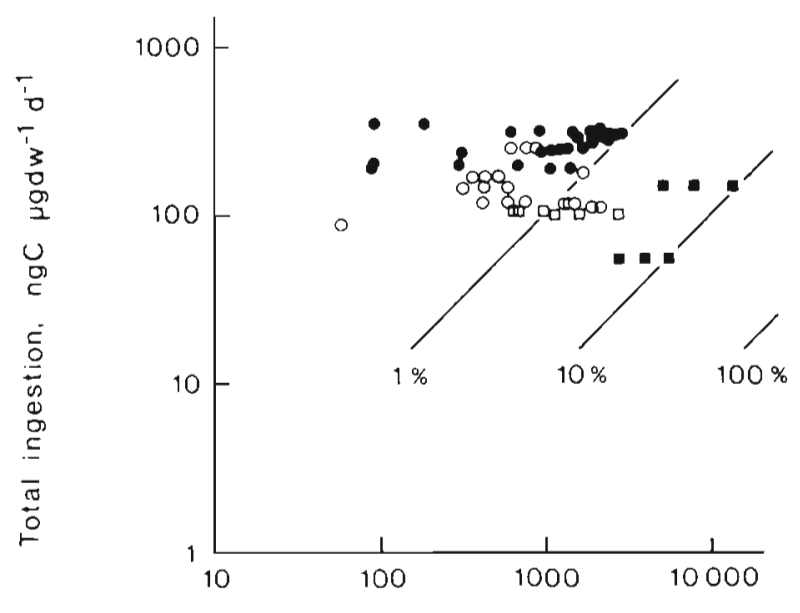

Ingestion of ciliates, $\mathrm{pgC \mu} \mu \mathrm{gdw} w^{-1} \mathrm{~d}^{-1}$

Fig. 5. Acartia sp. and Centropages hamatus. Total ingestion estimated from egg production measurements versus ingestion of ciliates. (o) C. hamatus ingestion, other legends as in

Fig. 4. Lines show percentage of diet attributed to ciliates

ingested ciliates represented less than $1 \%$ of total carbon ingestion for $A$. clausi and the highest proportion, $10 \%$, of total carbon ingestion was observed in the incubations from the Baltic. Proportions near $1 \%$ were found for $C$. hamatus as well.

\section{DISCUSSION}

Small coastal copepods are considered to be largely omnivorous and capable of feeding on a wide selection of food items. Phytoplankton are generally the most abundant food source but size distribution and palatability are factors that may prevent copepods from eating them at times. Aloricate ciliates are in the size range of the retention spectrum of most copepods but usually scarce compared with phytoplankton. Still, copepods could obtain an important part of their food from ciliates even at times of low ciliate abundance, if clearances on ciliates were considerably higher than on phytoplankton. The presumably higher nutritional value of ciliates would make them a preferred prey for copepods and their low availability would be counteracted by higher electivity by the predators.

Clearance rates for Acartia clausi were dependent on size of ciliate up to $25 \mu \mathrm{m}$ ESD (Fig. 2). The retention spectrum is similar to that found by Nival \& Nival (1976) where $100 \%$ efficiency of capture was achieved above ca $20 \mu \mathrm{m}$. Problems with handling of big particles (Nival \& Nival 1976) were not observed up to a ciliate size of $50 \mu \mathrm{m}$ ESD since clearance of these ciliates remained high. Clearance by Centropages hamatus also showed a steady increase with ciliate size but never reached a plateau and $100 \%$ efficiency of capture was probably achieved for food items over $50 \mu \mathrm{m}$ ESD (Fig. 3). This may reflect the larger size of C. hamatus since optimum food particle size appears to increase with increasing size of copepods (Berggreen et al. 1988). In the following discussion I will only consider $A$. clausi since the available information on feeding of $C$. hamatus is very limited. Furthermore, I assume that $A$. clausi and $A$. tonsa are similar in their feeding characteristics if the size difference is compensated for by using weight-specific clearance rates.

When examining the variation in clearance with size for both Acartia clausi and A. tonsa, there does not seem to be any difference between algae and ciliates as food particles (Fig. 6). There is a bias in the data because most small food items are algae and larger ones are ciliates. Hence, a strict comparison can only be made in the 15 to $30 \mu \mathrm{m}$ ESD size range where both algae and ciliates are present. In this size range,

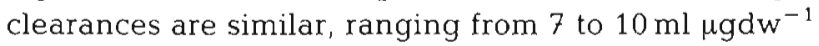
$\mathrm{d}^{-1}$. Moreover, the bell shaped curve (Berggreen et al, 1988) is supported by the inclusion of ciliate data in the 20 to $70 \mu \mathrm{m}$ size range. Thus, analyzing the data on ciliates from this study and from Stoecker \& Egloff (1987), it is clear that aloricate ciliates 30 to $40 \mu \mathrm{m}$ ESD are also cleared at maximum rate and that clearances decline below and above this size in the same way as for algae in Berggreen et al. (1988). No sign of preference or selectivity for ciliates by $A$. clausi was there- 


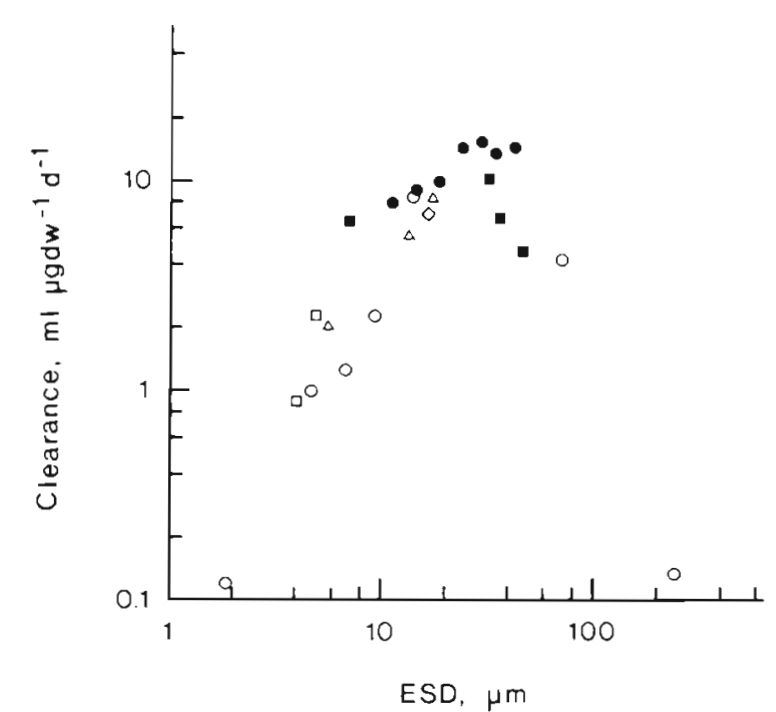

Fig. 6. Acartia clausi and A. tonsa. Clearance rates as a function of food particle size. Data on clearances of ciliates (filled symbols) and algae (open symbols) for A. clausi (this study: Ayukai [1987]: $\triangle$ ) and for $A$ tonsa (Stoecker \& Sanders [1985]: $\diamond$; Stoecker \& Egloff [1987]: $\square$, ${ }_{i}$ Berggreen et al. [1988]: 0 ). Dry weight of females (from length-weight regressions in Durbin \& Durbin 1978) assumed to be 3.5 in this study and $3.0,10.2,10.2$ and $9.3 \mu \mathrm{g}$, respectively, for the reference data

fore evident in this study of natural ciliate assemblages.

Particle sizes in Fig. 6 are given as equivalent spherical diameter (ESD) and all the particles used were relatively spherical compared, for instance, to tintinnids. Large tintinnids are probably captured differently from smaller aloricate ciliates, indicated by empty and crumbled lorica (Stoecker \& Sanders 1985). The crucial factor for the copepods' ability to ingest them might be the tintinnids' oral diameter rather than their total size and therefore they cannot be readily compared with the data in Fig.6. High clearance rates have been reported from feeding studies with large tintinnids, ranging from 15 to $26 \mathrm{ml} \mu g d w^{-1} \mathrm{~d}^{-1}$ (Robertson 1983, Stoecker \& Sanders 1985, Ayukai 1987), but are comparable to the peak clearance in Fig. 6.

Stoecker \& Egloff (1987) showed that for Acartia tonsa the clearance of the ciliate Balanion sp. $(33 \mu \mathrm{m}$ ESD) was much higher than clearances of the small phytoplankter Pyramimonas sp. ( 3 to $4 \mu \mathrm{m}$ ESD) or Chaetoceros simplex ( 5 to $6 \mu \mathrm{m}$ ESD). However, these algae are so small that the low clearance could be attributed largely to the copepods inability to catch them. For comparison, algae of similar size yielded clearances of 0.2 to $1.3 \mathrm{ml} \mu \mathrm{gdw}^{-1} \mathrm{~d}^{-1}$ (Fig. 6) and $<1.3$ $\mathrm{ml} \mu \mathrm{gd} \mathrm{w}^{-1} \mathrm{~d}^{-1}$ (Reeve \& Walter 1977). The increased clearance on ciliates might therefore be a result more of prey size than of the prey being a ciliate per se.

At the ciliate abundances found in this study, the contribution from aloricate ciliates to the diet of Acartia clausi and Centropages hamatus was negligible (Fig. 5). In contrast, aloricate ciliates made up 3 to $41 \%$ of total carbon ingested by $A$. tonsa in a highly productive coastal embayment (Gifford \& Dagg 1988). Ciliate concentrations in that study were higher $(1.8$ to $12.5 \mathrm{\mu g}$ $\mathrm{Cl}^{-1}$ ) than those found here and the phytoplankton was dominated by $<5 \mu \mathrm{m}$ flagellates. Gifford \& Dagg's (1988) January experiment is comparable to the Baltic situation in this study and the microzooplankton also accounted for a similar fraction of total ingestion $(3 \%$ compared to 5 to $7 \%$ in the Baltic).

For the Kattegat and the Skagerrak samples total ingestion was unrelated to ingestion of ciliates whereas in the Baltic (albeit only 2 samples) an increase in total ingestion was associated with increasing ingestion of ciliates (Fig. 5). This indicates that if ingestion of ciliates is high enough, in this case $>10 \%$ of total ingestion, a stimulation of egg production might occur. This was observed in Stoecker \& Egloff (1987) where high egg production rates were increased further when ciliates were added until they comprised 23 to $28 \%$ of available prey carbon.

Such high ciliate biomasses $\left(84 \mu \mathrm{gC} \mathrm{I}^{-1}\right.$ ) are, however, seldom attained in coastal waters (Table 1). Ciliate concentrations in the present study were comparable to previous reports from coastal and shelf regions (Sherr et al. 1986, Burkill et al. 1987, Gifford 1988) and comprised $<2.9 \%$ of phytoplankton carbon estimated from chlorophyll a concentrations. A low ciliate fraction was also found in the Gulf of Maine, USA, where ciliate biomass ranged from 0.04 to $3.6 \mu \mathrm{gC} \mathrm{l}^{-1}$ and represented $<3 \%$ of the available food for copepods (Montagnes et al. 1988). Slightly higher biomasses were recorded further offshore in a frontal region on Georges Bank where chlorophyll-containing aloricate ciliates ranged from 0.7 to $7.3 \mu \mathrm{gC} \mathrm{^{-1 }}$ (Stoecker et al. 1989) but still the ciliate fraction was low. Therefore, since the biomass of ciliates is generally low compared to phytoplankton biomass, it is only during periods of mass occurrences that they may form a significant portion of food available to copepods. Thus, the ciliate 'link' between the microbial loop and copepods (Sherr \& Sherr 1988) appears not to be a particularly strong one.

However, it should be remembered that copepods do not feed on average concentrations of algae or ciliates. Patchy horizontal distributions have been reported on a small scale in a pond (Stoecker et al. 1984) and on a larger scale in connection with fronts offshore (Stoecker et al. 1989). In the Kosterfjord in the eastern Skagerrak, biomasses of Strombidium sp. occasionally reach ca $15 \mu \mathrm{gC} \mathrm{l}^{-1}$ during summer in surface waters (P. Jonsson pers. comm.). Blooms of ciliates can be very short-lived and durations less than 3 to $5 \mathrm{~d}$ were 
observed by Andersen \& Sörensen (1986). Moreover, ciliates tend to aggregate in thin layers, usually close to the surface or at the pycnocline (Jonsson 1988, Stoecker et al. 1989). Jonsson (1988) sampled oligotrich ciliates every $0.2 \mathrm{~m}$ in the upper $5 \mathrm{~m}$ and frequently observed 5-fold changes in abundance over such short depth intervals as $0.5 \mathrm{~m}$.

Thus, the occurrence of ciliates seem to vary widely both in time and space and the resulting in situ aggregations (as well as the copepods' feeding response to these concentrations) are likely to be missed in an ordinary sampling procedure (i.e. bottle casts). Still, these ephemeral aggregations of food may be important for the growth and production of small copepods with limited capacity to store food energy. Studies of the fine-scale temporal and spatial distribution of copepod feeding activity (although difficult to perform) will be the key to answer the question of whether or not ciliates are an important food source for copepods.

Acknowledgements. I thank Thomas Kiorboe for continuing encouragement and criticism during this investigation. I also thank Jarl-Ove Stromberg and the staff at Kristineberg Marine Biological Station for providing good working facilities. Thanks are due to the crews on RV 'Ophelia' and RV 'Dana' for assistance during the cruises, and to Sif Johansson and the staff at Asko Laboratory. Jon Havenhand, Rutger Rosenberg, Per Jonsson and 2 anonymous referees helped improve the manuscript. Financial support was provided by the Swedish Environmental Protection Board, contract no. 5312338-6 and a grant from the Hierta-Retzius Foundation

\section{LITERATURE CITED}

Andersen, P. (1986). Undersögelser af protozooplankton i Limfjorden 1985. Limfjordskomiteen report nr. 35

Andersen, P., Sörensen, H. M. (1986). Population dynamics and trophic coupling in pelagic microorganisms in eutrophic coastal waters. Mar. Ecol. Prog. Ser 33: 99-109

Ayukai, $T$ (1987). Predation by Acartia clausi (Copepoda: Calanoida) on two species of tintinnids. Mar. Microb. Food Webs $2: 45-52$

Berggreen, U., Hansen, B., Kiørboe, T (1988). Food size spectra, ingestion and growth of the copepod Acartia tonsa during development: implications for the determination of copepod production. Mar. Biol. 99: 341-352

Burkill, P. H., Mantoura, R. F. C., Llewellyn, C. A., Owens, N. J. P. (1987). Microzooplankton grazing and selectivity of phytoplankton in coastal waters. Mar. Biol. 93: 581-590

Durbin, E. G., Durbin, A. G. (1978). Length and weight relationships of Acartia clausi from Narragansett Bay, R. I. Limnol. Oceanogr. 23: 958-969

Eppley, R. W., Harrison, W. G., Chisholm, S. W., Stewart, E. (1977). Particulate organic matter in surface waters off southern California and its relationship to phytoplankton. J. mar. Res. 35; 671-696

Frost, B. W. (1972). Effects of size and concentration of food particles on the feeding behavior of the marine planktonic copepod Calanus pacificus. Limnol. Oceanogr. 17: 805-815

Frost, B. W. (1987). Grazing control of phytoplankton stoock in the open subarctic Pacific Ocean: a model assessing the role of mesozooplankton, particularly the large calanoid copepods Neocalanus spp. Mar Ecol. Prog. Ser. 39: 49-68

Gifford, D. J. (1986). Grazing on natural microzooplankton assemblages by the copepod Acartia tonsa. EOS 67.967

Gifford, D. J. (1988). Impact of grazing by microzooplankton in the Northwest Arm of Halifax Harbour, Nova Scotia. Mar. Ecol. Prog. Ser, 47 249-258

Gifford, D. J., Dagg, M. J. (1987). Consumption of ciliate microzooplankton by Neocalanus plumchrus in the subarctic north Pacific Ocean. EOS 68: 1705

Gifford, D. J., Dagg, M. J. (1988). Feeding of the estuarine copepod Acartia tonsa Dana: carnivory vs. herbivory in natural microplankton assemblages. Bull. mar Sci. 43: $458-468$

Heinle, D. R., Harris, R. P., Ustach, J. F., Flemer, D. A. (1977). Detritus as food for estuarine copepods. Mar. Biol. 40: $341-353$

Jonsson, P. (1988). Oligotrich ciliates in the sea: an experimental analysis of foraging, growth dynamics and orientation in heterogeneous environments. Ph. D. dissertation, University of Göteborg, Sweden

Kiørboe, T., Möhlenberg, F., Riisgård, H. U. (1985). In situ feeding rates of four planktonic copepods: a comparison of four methods. J. exp. mar. Biol. Ecol. 88: 67-81

Klein Breteler, W. C. M., Fransz, H. G., Gonzalez, S. R. (1982). Growth and development of four calanoid copepod species under experimental and natural conditions. Neth. J. Sea Res. 6: 195-207

Kleppel, G. S. (1987). Diet and egg production of the copepod Acartia tonsa off southern California. EOS 68: 1731

Kleppel, G. S., Frazel, D., Pieper, R. E., Holliday, D. V (1988), Natural diets of zooplankton off southern California. Mar Ecol. Prog. Ser. 49: 231-241

McKellar, H., Hobro, R. (1976). Phytoplankton-zooplankton relationships in 100-liter plastic bags. Contrib. Askö Lab. Univ. Stockholm, Sweden, No. 13

Montagnes, D. J. S., Lynn, D. H., Roff, J. C., Taylor, W. D. (1988). The annual cycle of heterotrophic planktonic ciliates in the waters surrounding the Isles of Shoals, Gulf of Maine: an assessment of their trophic role. Mar Biol. 99: 21-30

Nival, P., Nival, S. (1976). Particle retention efficiencies of an herbivorous copepod, Acartia clausi (adult and copepodite stages): effects on grazing. Limnol. Oceanogr. 21: 24-38

Paranjape, M. A., Conover, R. J., Harding, G. C., Prouse, N. J. (1985). Micro- and macrozooplankton on the Scotian Shelf in the prespring bloom period: a comparison of their potential resource utilization. Can. J. Fish. Aquat. Sci. 42. $1484-1492$

Reeve, M. R., Walter, M. A. (1977). Observations on the existence of lower threshold and upper critical food concentrations for the copepod Acartia tonsa Dana. J. exp. mar. Biol. Ecol. 29: 211-221

Robertson, J. R. (1983). Predation by estuarine zooplankton on tintinnid ciliates. Estuar. coast. Shelf Sci. 16: 27-36

Sahlsten, E., Sörensson, F., Pettersson, K. (1988). Planktonic nitrogen uptake in the south-eastern Kattegat. J. exp. mar Biol. Ecol. 121: 227-246

Sheldon, R. W., Nival, P., Rassoulzadegan, F. (1986). An experimental investigation of flagellate-ciliate-copepod food chain with some observations relevant to the linear biomass hypothesis. Limnol. Oceanogr. 31: 184-188

Sherr, E., Sherr, B. (1988). Role of microbes in pelagic food webs: a revised concept. Limnol. Oceanogr. 33: 1225-1227

Sherr, E. B., Sherr, B. F., Fallon, R. D., Newell, S. Y. (1986). Small, aloricate ciliates as a major component of the marine heterotrophic nanoplankton. Limnol. Oceanogr 31: $177-183$ 
Smetacek, V (1981). The annual cycle of protozooplankton in the Kiel Bight. Mar. Biol. 63: 1-11

Stoecker, D. K. (1988). Feeding on Protozoa by marine macroplankton. EOS 69: 1117

Stoecker. D. K., Egloff, D. A. (1987). Predation by Acartia tonsa Dana on planktonic ciliates and rotifers. J. exp. mar Biol. Ecol. 110: 53-68

Stoecker, D. K., Davis, L. H., Anderson, D. M. (1984). Fine scale spatial correlations between planktonic ciliates and dinoflagellates. J. Plankton Res. 6: 829-842

Stoecker, D. K., Sanders, N. K. (1985). Differential grazing by Acartia tonsa on a dinoflagellate and a tintinnid. J. Plankton Res. 7: 85-100

Stoecker, D. K., Taniguchi, A., Michaels, A. E. (1989). Abun-

This article was presented by Dr T Kiørboe, Charlottenlund, Denmark dance of autotrophic, mixotrophic and heterotrophic planktonic ciliates in shelf and slope waters. Mar. Ecol. Prog. Ser. 50: 241-254

Strathmann, R. R. (1967). Estimating the organic carbon content of phytoplankton from cell volume or plasma volume. Limnol. Oceanogr. 12: 411-418

Turner, J. T., Anderson, D. M. (1983). Zooplankton grazing during dinoflagellate blooms in a Cape Cod embayment, with observations of predation upon tintinnids by copepods. P. S. Z. N. I. Mar. Ecol. 4: 359-374

Verity, P. G. (1986). Grazing of phototrophic nanoplankton by microzooplankton in Narragansett Bay. Mar. Ecol. Prog. Ser. 29: 105-115

Manuscript first received: February 14, 1989

Revised version accepted: May 11, 1989 